\title{
Visual Metafunction of Multimodal Text Nabelken Gelar of Karonese Culture
}

\author{
Ernawati Br Surbakti ${ }^{1}$, Yusnimar ${ }^{2}$, Wahdaniah ${ }^{3}$ \\ \{ernawati@pnl.ac.id ${ }^{1}$, yusnimar@pnl.ac.id ${ }^{2}$,wahdaniah@pnl.ac.id ${ }^{3}$ \} \\ ${ }^{123}$ Politeknik Negeri Lhokseumawe Lhokseumawe, Aceh, Indonesia
}

\begin{abstract}
This qualitative research aims to describe visual metafunction of multimodal text nabelken gelar in Karo ethnic and to describe intersemiotic relations between verbal and visual text of nabelken gelar. Data were analyzed by using visual metafunction of Ideational, Interpersonal and Component of representation. Based on the result of analysis, It was found data of multimodal text in nabelken gelar. The data of multimodal text in nabelken gelar has (1) Ideational function such as Process (action, verbal, analytical, symbolic, and mental), Participant including Participant I (actor, carrier, goal, senser and sayer) and Participant II (goal, symbolic attributive, and utterance), and Circumstance (place); (2) Interpersonal function consists of contact (demand and offer), social distance (intimate dan equality), and point of view (viewer power and represented participant power); (3) Textual function consists of information values (centred and new), salience (the contrast colours in ethnic clothes of father and mother, mat and Jambur tent border and also framing. Both verbal and visual texts in nabelken gelar contain messanges. Logic lntersemiotic relations between verbal and visual texts in transferring the meaning of multimodal text in nabelken gelar consist of repeating, comparative, additive, consequential (consequence and contingency).
\end{abstract}

Keywords- Karonese culture, multimodal, visual metafunction, nabelken gelar (giving name to newborn baby).

\section{Introduction}

An expression stating what's in a name is agreed by people in general, but it does not apply to Karonese. Karonese have a cultural tradition called nabelken gelar. It is a ceremony which is held to tie a name to a baby, legitimize it by inviting sangkep ngeluh so that the name will be tangkel (suitable and attached to the baby). Karonese people do not name their babies based on which names are good or not, but based on whether the names are suitable for the babies. Sometimes if the name is not suitable, the baby can get sick, has a bad future and so on, which is a bad thing for Karonese. Name is a very important thing because for them the beginning of a life stage starts from a baby.

According to other ethnic groups, Karonese names are very unique because they are related to certain conditions of nature, things, activities or Karonese ideology. They also put their family names at the end of their names. Since the suitability is very important, they hold a 
tradition of nabelken gelar. In this tradition, the name has been prepared by a chief of tribal council who knows tradition and believed to have sixth sense. In the process of attachment and legalization, they invite the baby's sangkep ngeluh. Thus, nabelken gelar either to the newlyborn sons or daughters has become one of cultural wealth of Karo.

Yanda and Ramadhanti (2018), in the analysis of a multimodal discourse analysis (mda) on clear-eyed angel novel by Habiburrahman el-shirazy used a multimodal semiotic approach to study images, colors, and the texts on the cover of the novel that reflected the contents of the novel [1]. Pictures and colors were analyzed using Kress and Leeuwen's theory of image reading, while the texts as a reflection of reality was analyzed using the theory of seven building tasks from James Paul Gee. This study concludes that in the use of colors, images and texts contain certain meanings that can be interpreted by the reader in accordance with the reality presented in the text or narration. Differences in analysis of a multimodal discourse analysis (mda) on a clear-eyed nymph novel by Habiburrahman el-shirazy with this study analyzes cultural discourse. The equation examines text combined with images, colors, symbols and other semiotic sources.

Wulan (2017) in the Discourse Analysis and Education: Multimodal Semiotic Indonesian Cartoon "Adit Sopo Jarwo of Missing Meatballs Episode" Vs. Malaysian Cartoon "Upin-Ipin Episode Ecosystem said that cartoons are an audiovisual media which includes various kinds of writing as a support [2]. The elements known in this article are linguistic analysis and visual analysis. Cartoons can be used as learning material because in them there are many messages or messages, especially for children who are starting to lose their childhood due to technological developments and television shows that are less supportive of children's development. The multimodal analysis discussed in this paper uses the theory of verbal text analysis in the language metafunction of ideational functions, interpersonal functions, and textual functions, the model proposed by Halliday (1994), while visual text uses multimodal analysis [3], [4]. The difference lies in the object of data analysis and the similarity of multimodal analysis.

Sari (2017) in the Multimodality analysis of Luwak White Koffie Lee Min-Ho Version Advertisement analyzes the hidden meaning of Luwak White Koffie's poster ad on the Facebook page in 2016 with Lee Min-Ho as brand ambassador. The method used in this study is qualitative with the main data source of advertising posters on Lee Min-Ho's 2016 version of Luwak White Koffie's Facebook page. The results of the meaning of this advertising poster show a representation of fantasy about drinking coffee [5]. The three metaphysics above show that there is a shift from the focus of coffee products to the focus on brand ambassadors. The excessive focus on brand ambassador Lee Min-Ho on this ad poster aims to attract the attention of young consumers who are actively using social media. Differences in analysis of Multimodality In Civet White Koffie Lee Min-Ho Version Advertisement with this study is the difference in object and context of analysis. The equation uses a semiotic social analysis from Kress and van Leeuwen about multimodality which consists of representational, interpersonal, and compositional metaphors to analyze the elements and meanings in the text.

Ademilokun and Olateju (2016) in the study of A Multimodal Discourse Analysis of Some Visual Images in the Political Rally Discourse of the 2011 Election Campaign in Southwestern Nigeria. The data comprised purposively selected political visual artefacts from political rallies across the six Southwestern States in Nigeria (Osun, Oyo, Ondo, Ekiti, Ogun, and Lagos). The data were analyzed using Halliday's (2004) systemic metafunctional principles and Barthes' (1977) concepts of anchorage and relay [6], [7]. The study noted that, vests are the commonest type of semiotic artifact while caps, Ankara, and surrogate languages complement the use of vests for visual signification and meaning potentials in the discourse environment. The study also noted that various political party colors reflect almost all the visual images and they are suggestive of the ideology or the level of commitment and political leanings of discourse participants. The study concluded that, semiotic resources or artefacts are an important aspect of political rallies because of the inherent political, cultural, and social communication that is 
revealed through them. Difference A Multimodal Discourse Analysis of Some Visual Images in the Political Rally Discourse of 2011 Election Campaigning in Southwestern Nigeria with study ii is on the research object while the equation is multimodal analysis [8].

Kusmayadi (2015) in the study of Visual Street Art in Yogyakarta Public Space uses visual art as a form of resistance to social issues that occur in the social life of its people. Visual Street Art Study in Yogyakarta City Public Spaces uses qualitative methods. Street Art with social themes is the source of data in this study. This study uses a multimodality approach that prioritizes three communication metafunctions in social semiotic visual expression systems, namely the meaning of representation, the meaning of interaction and the meaning of composition in analyzing two modes of semiotics namely visual and verbal that appear in street art in public spaces in the city of Yogyakarta. The results showed that street art is a medium used by artists to convey messages in the form of appeals, criticism of problems that occur in the city of Yogyakarta. Street art tends to be narrative and conceptual in the form of symbols that are easily captured and close social distance as a representation of the people of Yogyakarta. Most works are stencil, and wheatpaste in black and white to make it easy to reproduce works [9].

From linguistic perspective, the language of nabelken gelar used in interaction between sangkep ngelluh (kalimbubu, senina, and anak beru) have meanings, for example lampas mbelin anakku keleng erkalimbubu (grow fast my dear child). Literally, this sentence is only a regular expression but it has a deep meaning for Karonese. Kalimbubu is dibata ni idah (the visible God). He is the brother of the mother who has a noble and respected position. Each of Sangkep ngelluh has their own role which has been formed from the ancestors and continue till today. They wear traditional clothes which are full of meanings and cultural values. It can be seen from the decription of motives and colours (modality) which is also a solid and great unity.

The purpose of this research is to describe the visual metafunction in multimodal text of nabelken gelar in Karonese tradition and also intersemiotic relations between verbal and visual text in nabelken gelar. The stages or procession of nabelken gelar begins with baba anak (bring the baby) leaving the house and go to jambur (a large building which is usually used by Karonese people to celebrate parties and traditional ceremonies); then in jambur sangkep ngelluh (family): kalimbubu, sembuyak (relatives), and anak beru (girls) ngelandeki anak si nabelken gelar (dance for the baby) which is being carried by his/ her mother; nabelken gelar; didong doah from bibina (aunt sings for the baby); kata pengalo-ngalo(give speech); kata pedah-pedah (advice) from kalimbubu; sembuyak; have lunch; speech from anak beru; mbereken luah (give presents), Landek (dance together) and ceremony is finished.

\section{Methods}

The method of research used in this paper is descriptive qualitative. The research location is in Jambur Tanjung Manggusta. In this research, primary and secondary data are used. The procession of nabelken gelar in Tanjung Manggusta is the primary data. The informants were the family who legitimized the Karo title. While secondary data were taken form written documents such as Karo language dictionary and books related to nabelken gelar. Data collecting was conducted from the nabelken gelar ceremony. Data were collected in the form of recording, written documents, in-depth interview, and participant observation.

The interview was in the form of conversation: asking and listening technique, and it is not a neutral device in producing reality. Therefore, there were so many answers given. The interview is a media to give situated understanding taken from special interactions [10]. The data were analyzed using the qualitative analitical technique [11]. The research began from the data gained from field observation. The data were then reduced in order that they could be 
presented and concluded. It was followed by selecting a supporting theory which was related to the data. The data analytical techniques used in the research were (1) transcribing oral data such as the utterances of anak beru into written form data; (2) visual data such as visual recording of nabelken gelar which then underwent data reduction; (3) data such as multimodal text of nabelken gelar which were analyzed using the theory of visual metafunctions; namely ideational, interpersonal and textual functions; (4) the data reduction results were presented in descriptions and pictures.

\section{Results and Discussion}

\subsection{Visual Metafunctions in Multimodal Text of Nabelken Gelar}
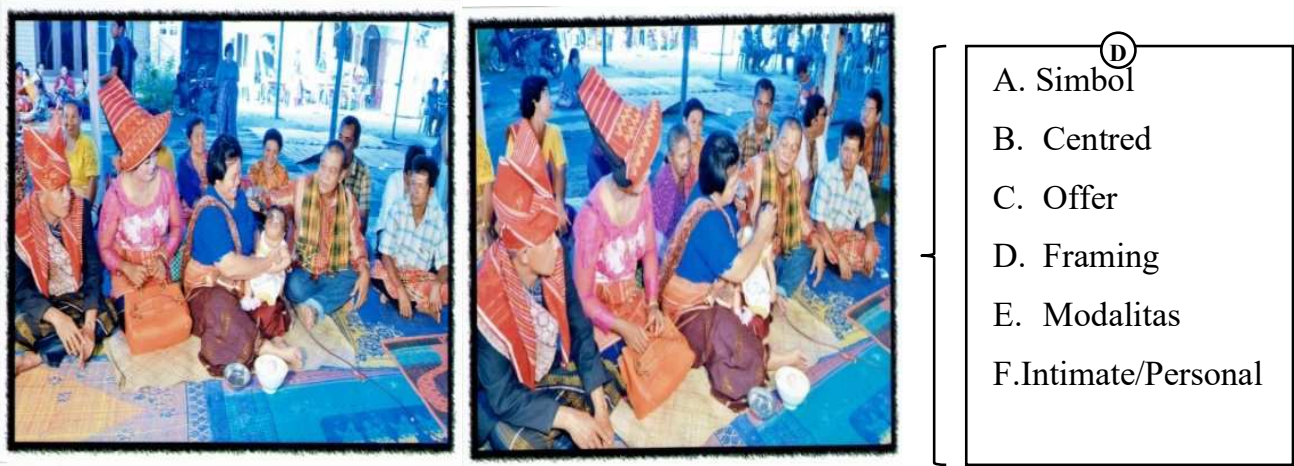

Fig. 1. Nabelken gelar by the child's aunt

Ideational Component. Wulandari Br Sembiring Depari Bre Surbakti gelarndu 'Wulandari Br Sembiring Depari Bre Surbakti is your name' was analysed by using ideational function; Wulandari Br Sembiring Depari Bre Surbakti was conducted in analytical process as symbolic attribute and gelarndu as carrier.

Interpersonal/Interactional Component. From the picture, there is not any demand since the angle was focused on the baby. Aunt, father, mother, kila and sembuyak si bibi and kila were acted as offer who were watching the baby. The pattern of participant is described in the form of viewer power which indicates the power toward themselves and this power is also owned by the people in the picture. The picture was shot closely to the people (intimate). The low modality of saturation is marked by black and white and high modality of color modulation is marked by color diversity and full shade. The high modality of contextualization is due to the detail color of Jambur/lost tent and mat which are bright. The high modality of representation is due to detailed representation, high modality of depth is due to clear perspectives, high modality illumination is due to lighting and high modality of brightness is due to high level of brightness. Textual component is represented in the composition: the baby is called centred or a center of the picture, bibi nirciri beras piher which was put into a white bowl (pasu) with eggs on top of it as symbolic attribute. Beras piher means the baby and aunt still act as salience in the picture. Aunt says her prayers and hopes that the name is suitable, makes the baby healthy and gives him better future. Framing is not part of the picture. 


\subsection{The Logic Inter-Semiotic Relation Between Verbal and Visual Texts in Delivering Meanings of Nabelken Gelar Multimodal Text}

The semiotic source in the research is verbal and visual signs in the form of verbal and visual texts of Nabelken Gelar. Both text models have a relation to one another in creating meanings. The logic inter-semiotic relation between verbal and visual texts in delivering meanings of nabelken gelar multimodal text indicates that verbal text in the form of verbal signs can not stand alone in creating a meaning. Therefore, visual text is required as in the text of Nabelken Gelar.

1. Repeating relation occurs in verbal text lampas mbelin, sehat-sehat lupa ngindet, lupa mbatuk, seh sura-surandu, ula kisat suruh ninina were utterred repeatedly and so was the visual text. This repeating relation describes and emphasizes verbal and visual texts of nabelken gelar anak ceremoy and indicates as the main ceremony. The texts include praying and hoping that the baby is healthy, her name is suitable, has a good attitute and character and can reach her ambition when she has grown up.

2. Comparative relation occurs in the text ula kisat suruh ninina as an action process and visual of ninina is blessing or praying for the baby by putting beras piher on the baby's head. Thus, the baby will become a good and diligent daughter based on his grandmother's expectation. Beras piher is a symbol of a good soul and health. Therefore, verbal text has a general comparative relation. The action of grandmother (actor) is a physical activity namely putting rice on the baby's head. Sehlah surasurandu bere-bere mamana is a symbolic process of sura-sura si anak and visual of mama is kalimbubu (the most respectful person in rakut sitelu) who puts a high expectation that someday the daughter can reach his ambition. The comparative relation occurred between visual and verbal texts is a relation of abstraction. The meaning of visual and verbal texts is family happiness and rakut sitelu for the born of the baby who wished to become a good daughter, have good attitute, respect to kalimbubu, sembuyak, anak beru and reach his ambition.

3. Additive Relation is verbal text wulandari br sembiring depari bre surbakti gelarndu was uttered with the visual of beras piher which was put on the baby's head so that the name is suitable and the baby is healthy. In Karo culture, daughter who ditabelken gelar was carried by the sister of her father 'bibi' after nabelken gelar ceremony, tutur sitelu such as kalimbubu will pray for her with the visual of putting rice on her head. The meaning of verbal and visual texts in additive relation is the happiness of Depari's family with kalimbubu, sembuyak, anak beru and other sangkep ngeluh for the ceremony of nabelken gelar and hope that the baby become a good and healthy daughter and can reach her ambition in the future.

4. Consequential Relation (a) consequential; concequence happened in verbal text lampas mbelin jujuri dibata kempu ninina which represented by visual with the effect of touching and putting rice on the baby's head repeatedly, (b) concequential; contingency is a relation that refers to an unabsolute effect. Verbal text iah alep-alep-alep does not refer to an absolute visual effect because the visual of the baby carried by aunt to jambur is not similar with verbal text alep-alep-alep.

After selecting data of visual metafunction, it is found that not every data fulfills the requirement of ideational, interpersonal and textual components which is based on Kress dan van Leeuwen $(1996,2006)$. The findings showed that not all process found in representation component. It is found that dominant process is action (54.54\%). Verbal process is $18.18 \%$, analytical process is $9.09 \%$, symbolic process is $9.09 \%$, and mental process is $9.09 \%$. 
Classifical process, reaction and conversion are not found. Based on the findings, in Karo culture nabalken gelar is a physical activity that occurs outside of human's body.

Participant I is dominantly actor (36.36\%) then carrier $(27.27 \%)$, goal $(18.18 \%)$ and senser and sayer with the same Percentage of $9,09 \%$. It indicates that Participant I is dominantly human namely kalimbubu as rakut sitelu who is respected and gives more advice to the baby in nabelken gelar and anak beru whose responsibility is to run the ceremony.

Participant II is dominantly goal (50\%), then utterance $(25 \%)$, symbolic attribute $(12,5 \%)$ and symbolic attribute (12,5\%). Goal as dominant Participant II is in line with action as dominant process in which actor acted as Participant I. Goal refers to baby, sembuyak, Depari's family including father, mother and circumstance. Dominant circumstance is the location of nabelken gelar ceremony namely Jambur Tanjung Manggusta.

1. Interactional component

In contact, demand is $20 \%$ and offer is $80 \%$ which means that offer dominantly gives information than receives information. Offer includes bibi who was carrying the baby, the baby, father, mother and sangkep ngelluh. All data pictures contain social distance of intimate and equality which means that they show the closeness and togetherness of sangkep ngelluh in nabelken gelar ceremony. Description pattern of participants are viewer power $(80 \%)$ which is stronger and represented participant power $(20 \%)$ which is weak. It means that participants are more salient in nabelken gelar pictures. Modality in nabelken gelar pictures is high in colour modulation, colour differentiation, colour saturation, contextualization, representation, depth, illumination and brightness. While the low modality tends to occurs in colour saturation.

2. Composition Component

Dominant information value is placed in the center or centred $(90 \%)$ while $10 \%$ of information value is displayed in the right side which means it gives a new information (new). Salience in the picture of nabelken gelar is found in father and mother's clothes, mats and tents beside jambur which have very contrast colours compared with others. Framing in nabelken gelar pictures is defined as everything that marks the limit of the picture.

\section{Conclusion}

The conclusions that can be drawn based on the data analysis and findings are that multimodal text of nabelken gelar consists of (1) ideational function including Process (action, verbal, analytical, symbolic, and mental), Participants (Participant I (actor, carrier, goal, senser and sayer) and Participant II (goal, symbolic atributif, and utterance)), and Circumstance (location); (2) interpersonal function including contact (demand and offer), social distance (intimate and equality), and point of view (viewer power and represented participant power); (3) textual function including information values (centred and new), salience (contrast colours in father and mother's traditional clothes, mats, and tents in the side of Jambur), and framing. Verbal and visual texts of nabelken gelar have the same potential to explain meanings. The logic inter-semiotic relation between verbal and visual texts in delivering meanings of multimodal text in nabelken gelar consists of repeating, comparative, additive, and consequential (consequence and contingency) relations. 


\section{References}

[1] D. P. Yanda and D. Ramadhanti, "A Multimodal Discourse Analysis (Mda) On Bidadari Bermata Bening Novel By Habiburrahman El-Shirazy (Analisis Wacana Multimodal Dalam Novel Bidadari Bermata Bening Karya Habiburrahman El-Shirazy)," J. Gramatika J. Penelit. Pendidik. Bhs. dan Sastra Indones., vol. 4, no. 2, pp. 214-226, 2018.

[2] A. P. Wulan, "Analisis Wacana dan Edukasi: Semiotik Multimodal Kartun Indonesia "Adit Sopo Jarwo Episode Bakso Hilang' Vs Kartun Malaysia "Upin-Ipin Episode Ekosistem"," in The 5th Urecol Proceeding, 2017, pp. 1104-1117.

[3] M. A. K. Halliday, An Introduction to Functional Grammar (2nd Edition). London and New York: Edward Arnold, 1994.

[4] G. Kress and T. van Leeuwen, Reading images: the grammar of visual design. London: Routledge, 2006.

[5] Y. Sari, "Multimodalitas Dalam Gambar Iklan Luwak White Koffie Versi Lee Min-Ho," Metalingua, vol. 15, no. 2, pp. 235-243, 2017.

[6] M. A. K. Halliday and C. M. I. M. Matthiessen, An Introduction to Functional Grammar Third Edition. Great Britain: Edward Arnold, 2004.

[7] R. Barthes, Image, Music, Text. London: Fontana Press, 1977.

[8] M. Ademilokun and M. Olateju, "A Multimodal Discourse Analysis of Some Visual Images in the Political Rally Discourse of 2011 Electioneering Campaigns in Southwestern Nigeria," Int. J. Soc. Cult. Langguage, vol. 4, no. 1, pp. 1-19, 2016.

[9] D. M. Kusmayadi, "Kajian Visual Street Art Di Ruang Publik Kota Yogyakarta," Vis. Art Disign J., vol. 3, no. 3, pp. 270-280, 2015.

[10] N. K. Denzin and Y. S. Lincoln, Handbook of Qualitative Research. Yogyakarta: Pustaka Pelajar, 2009

[11] M. B . Miles and A. M. Huberman, Analisis Data Kualitatif. Jakarta: Universitas Indonesia Press, 1984. 